\title{
CORONAVIRUS ANXIETY SCALE DEVELOPMENT FOR HEALTHCARE EMPLOYEES
}

\author{
Mustafa $\mathrm{Nal}^{{ }^{*}} \bowtie(\mathrm{D})$, Burcu $\mathrm{Nal}^{2}$ (iD) \\ ${ }^{* 1}$ Department of Insurance and Actuarial, Afyon Kocatepe University, Turkey \\ ${ }^{2}$ First and Emergency Aid Department, Suleyman Demirel University, Turkey
}

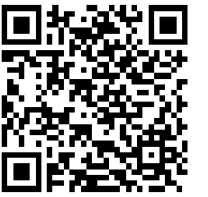

DOI: https://doi.org/10.29121/granthaalayah.v9.i2.2021.3508

Article Type: Research Article

Article Citation: Mustafa Nal, and Burcu Nal. (2021). CORONAVIRUS ANXIETY SCALE DEVELOPMENT FOR HEALTHCARE EMPLOYEES. International Journal of Research GRANTHAALAYAH, 9(2), 149-156. https://doi.org/10.29121/granthaa layah.v9.i2.2021.3508

Received Date: 02 February 2021

Accepted Date: 26 February 2021

Keywords:

Coronavirus Anxiety Scale

Health Employee

Scale Development

COVID-19

\begin{abstract}
The aim of this study was to develop a scale that includes occupational features to measure the coronavirus anxiety levels of healthcare professionals. The research was carried out on healthcare employees and convenience sampling method was used. 106 health employees participated in the first pilot, and 209 health employees participated in the second pilot. The research data were collected by survey method. Data analysis was performed using IBM SPSS 25.0, IBM SPSS Amos 25.0 programs. As a result of the Explanatory Factor Analysis, it was determined that the scale consists of seven items and two factors. Confirmatory Factor Analysis was performed in order to examine the model fit of the scale, and as a result of the analysis, it was found that the scale was at a good level. The scale was found to be highly reliable (CA>0.80).
\end{abstract}

\section{INTRODUCTION}

Today, the pandemic caused by a virus called COVID-19 (Coronavirus) has affected the whole world and has become a threat to human life. The first case of COVID-19 was detected on December 12, 2019 in Wuhan, the capital of the Hubei region of China, and it is thought to spread to the world from here. The World Health Organization announced this epidemic caused by the COVID-19 virus as a pandemic on March 11, 2020 (Nal, 2020). The coronavirus pandemic has been going on all over the world for about a year. According to the data of the World Health Organization (WHO), the number of cases with coronavirus detected in the world as of December 2020 is 66 422058 and the number of deaths is 1532418.

The COVID-19 pandemic has changed the lives of people all over the world (Dinesh and MuniRaju, 2021). COVID19 virus can affect human health in two different ways. First, the virus can cause health problems directly on the human body, secondly, it causes mental health problems such as anxiety, panic and anxiety in people due to the epidemic (Așkın, Bozkurt and Zeybek, 2020).

Health employees are one of the professions most affected and at risk from this situation. It has been determined in the literature that there is no scale to measure the Coronavirus anxiety levels of healthcare employees. In order to fill this gap in the literature, it was aimed to develop a profession-oriented scale to measure the coronavirus anxiety levels of healthcare employees.

(C) 2021 The Author(s). This is an open access article distributed under the terms of the Creative Commons Attribution License, which permits unrestricted use, distribution, and reproduction in any medium, provided the original author and source are credited. 


\section{MATERIALS AND METHODS}

This research was conducted in a descriptive screening model to improve the coronavirus anxiety level of healthcare employees.

Survey method was used as data collection method. The convenience sampling method was used as the sampling method. Surveys prepared in electronic environment were shared with healthcare professionals and volunteers were enabled to participate in the research. In the first part of the questionnaire, a consent to inform the participants was added. Expressions that are not understood or need to be explained were requested to be consulted by mail.

IBM SPSS 25.0 (Statistical Package for the Social Sciences), IBM SPSS Amos 25.0 programs were programmed in the analysis of the data. Cronbach alpha value was calculated, Exploratory Factor Analysis (EFA) was performed to calculate the internal information of the scale, to determine the construct validity and implicit structure of the scale, and Confirmatory Factor analysis was performed to analyze the model fit of the scale.

\subsection{HEALTHCARE EMPLOYEE CORONAVIRUS ANXIETY SCALE DEVELOPMENT PROCESS}

All over the world, the COVID-19 pandemic has been going on for about a year. Coronavirus affects human health both physically and psychologically (Așkın, Bozkurt and Zeybek, 2020). It is thought that the occupational group most affected by this pandemic is healthcare employees. It was determined from the literature review that there is no special scale for measuring the anxiety level of healthcare employees. In order to fill this gap in the literature, it was decided to conduct this study.

In the literature, State Anxiety Scale and Trait Anxiety Scale developed by Spielberger et al. (1970), Death Anxiety Scale developed by Templer in 1970, Coronavirus Anxiety Scale developed by Lee (2020), Silva, Sampaio and Pereire (COVID-19 Anxiety Scale developed by 2020) was examined. Considering the expressions in these scales, a scale pool of 30 items was created. These items were reduced to 13 in line with the expert opinion and the opinions of the authors regarding the statements in the item pool. The items were reviewed by a language expert and necessary corrections were made in line with the language expert's suggestions. Scale items are designed in 5-point likert. The statements given the items were respectively determined as "Never, Rarely, Occasionally, Usually, Always". The first form of the scale was created in this way before the pilot application.

\section{RESULTS AND DISCUSSIONS}

In this section, the results of the analysis results regarding the reliability and validity of the Healthcare Employee Coronavirus Anxiety Scale (HECAS) are presented below.

\subsection{FIRST PILOT APPLICATION PARTICIPANTS}

Using the convenience sampling method, healthcare professionals working in different health institutions were included in the sample. For the pilot application, a sample size of around 50 is considered sufficient for scales with a sample size of up to 30 (Seçer, 2015). In addition, a sample size of 5 times the number of items is generally sufficient (Büyüköztürk, 2002). In this study, the sample size for the pilot study was determined to be 65, which is 5 times the number of items, and 106 healthcare employees participated in order to increase the reliability. Average age of the participants is $31.63 \pm 79,82.1 \%(n=87)$ female, $17.9 \%(n=19)$ male, 59.4\% married $(n=63), 40.6 \%(n=43)$ single, $4.7 \%(\mathrm{n}=5)$ high school graduates, $19.8 \%(\mathrm{n}=21)$ associate degree graduates, $64.2 \%(\mathrm{n}=68)$ undergraduate graduates, $11.3 \%(\mathrm{n}=12)$ graduates $94.3 \%(\mathrm{n}=100)$ work in the public sector, $5.7 \%(\mathrm{n}=6)$ work in the private sector, $66 \%(n=70)$ nurses, 9.4\% (n=10) emergency medicine technicians, $\% 8.5(n=9)$ were midwives, 6.6\% (n=7) health technicians, $5.7 \%(n=6)$ medical secretaries, 3.8\% $(n=4)$ other health personnel. The distribution of the participants in terms of working time in the health sector is $14.2 \%(n=15)$ for 1 year or less, $22.6 \%(n=24)$ for $2-5$ years, $63.2 \%$ $(n=67)$ for 6 years and has been working in the health sector for longer. 


\subsection{RELIABILITY ANALYSIS RESULT AFTER FIRST PILOT}

The fact that the Cronbach alpha value obtained in the pilot application is above 0.70 indicates that the scale has internal consistency (Seçer, 2015). After the first pilot, the Cronbach's alpha value of the Healthcare Employee Coronavirus Anxiety Scale (HECAS) was determined as 0.91 . This result shows that the scale has a high level of internal consistency. For this reason, the item was not removed from the scale. The statements in the scale were revised in line with the recommendations of the linguist and field experts, and it was decided to use the 13 items used in the scale in the second pilot application.

\subsection{SECOND PILOT PRACTICE SAMPLE}

The second pilot application was carried out with the participation of a total of 209 healthcare professionals. Average age of the participants $31.74 \pm 9.56,76.6 \%(n=160)$ female, $23.4 \%(n=49)$ male, 56.0\% married $(n=117)$, $44.0 \%(n=92)$ single, $24.4 \%(n=51)$ high school graduates, $21.5 \%(n=45)$ associate degree graduates, $30.6 \%(n=64)$ bachelor's degrees, $11.5 \%$ (24) graduate graduates, $64.6 \%(\mathrm{n}=135)$ work in the public sector, $35.4 \%(\mathrm{n}=74)$ work in the private sector, $63.6 \%(\mathrm{n}=133)$ nurses, $10.0 \%(\mathrm{n}=21)$ emergency medicine technician, 3.3\% $(\mathrm{n}=7)$ midwife, 9.6\% $(n=20)$ health technician, 4.8\% $(n=10)$ medical secretary, $6.2 \%(n=13)$ other the health personnel, $2.4 \%(n=5)$ of them, are physicians. The distribution of the participants by their working time in the health sector is $9.1 \%(n=19)$ for 1 year or less, $36.4 \%(n=76)$ for $2-5$ years, $54.5 \%(n=114)$ for 6 years and it has been determined that he has been working in the health sector for a longer time.

\subsection{SCALE ANALYSIS AFTER SECOND PILOT IMPLEMENTATION}

After the second pilot application, the Cronbach alpha value of the Coronavirus Anxiety Scale was determined as 0.90 . As a result of the total correlation analysis of the items, the lowest correlation value was determined as 0.295 (item 6) and the highest correlation value was found as 0.784 (item 12).

\subsection{EXPLANATORY FACTOR ANALYSIS (EFA) RESULTS}

Kaiser-Meyer-Okin (KMO) and Bartlett's tests were conducted to determine the suitability for the factor analysis of the sample size of the data set. The Kaiser-Meyer-Okin (KMO) value was determined as 0.85. According to Hutcheson and Sofroniou (1999), the KMO value between 0.80-0.90 shows that the sample size is at a very good level. Barlett's test value was determined as $916.96(\mathrm{p}<0.05)$. As a result of the Barlett test, it was determined that the data set is multivariate and has a normal distribution. Exploratory Factor Analysis (EFA) was conducted to determine the implicit structure of the scale. The method for determining the factor structure of the scale was determined as "maximum likelihood", as the score dimension 0.32. The rotation technique was not applied. As a result of the first-level Exploratory Factor Analysis, it was determined that the scale consisted of two factors, the ratio of explaining the total variance of the first factor was $46.55 \%$, the ratio of explaining the total variance of the second factor was $9.35 \%$, and the ratio of explaining the total variance of both factors was $55.90 \%$. Item 7, item 8 , and item 9 with a factor load value of less than 0.32 , item 1 and item 6 , under more than one factor and the difference between factor loads of less than 0.10 were excluded from the scale.

Factor analysis was repeated for the second time by performing rotation. The "Direct Oblimin" technique was used as the rotation technique. As a result of the process, it was determined that the scale consists of 7 items and two dimensions. As a result of Kaiser-Meyer-Okin (KMO) and Bartlett's tests, KMO value was determined as 0.842 . Barlett's test value was determined as $801.175(\mathrm{p}<0.05)$. As a result of the second stage Exploratory Factor Analysis, it was determined that the scale consists of two factors, the first factor explains the total variance as $52.10 \%$, the second factor explains the total variance as $11.58 \%$, and both factors explain the total variance as $63.68 \%$. Variance ratio varying between $40 \%$ and $60 \%$ in social sciences is accepted as normal values (Tavşancll, 2014). It is seen that the variance ratio obtained as a result of this analysis is at a sufficient level. When Table 1 is examined, it is seen that there are 7 items in the scale as a result of EFA. When the factor loadings were examined, it was found that the item load values of the first factor (items $10,11,12,13$ ) varied between 0.60 and 0.93 , while the item load values of the second factor (items $2,3,4$ ) varied between 0.72 and 0.85 . has been determined. As a result of the repeated reliability 
analysis, the Cronbach alpha value was determined as 0.86 . According to this result, it can be said that the scale is highly reliable.

Table 1: Results of exploratory factor analysis

\begin{tabular}{|c|c|c|c|c|c|c|}
\hline Factors & $\begin{array}{l}\text { Question } \\
\text { statements }\end{array}$ & $\begin{array}{l}\text { Factor } \\
\text { weight }\end{array}$ & $\begin{array}{c}\text { Factor disclosure } \\
\text { rate } \%\end{array}$ & Eigenvalue & Reliability & Mean \\
\hline \multirow{3}{*}{$\begin{array}{l}\text { Self anxiety } \\
\text { (Factor 2) }\end{array}$} & Item 2 & 0.728 & \multirow[t]{3}{*}{11.58} & \multirow[t]{3}{*}{1.19} & \multirow[t]{3}{*}{0.83} & \multirow[t]{3}{*}{2.13} \\
\hline & Item 3 & 0.828 & & & & \\
\hline & Item 4 & 0.859 & & & & \\
\hline \multirow{4}{*}{$\begin{array}{c}\text { Anxiety towards } \\
\text { patients } \\
\text { (Factor } 1 \text { ) }\end{array}$} & Item 10 & 0.605 & \multirow[t]{4}{*}{51.10} & \multirow[t]{4}{*}{3.97} & \multirow[t]{4}{*}{0.85} & \multirow[t]{4}{*}{2.45} \\
\hline & Item 11 & 0.938 & & & & \\
\hline & Item 12 & 0.810 & & & & \\
\hline & Item 13 & 0.723 & & & & \\
\hline Total & & & 63.68 & 5.16 & 0.86 & 2.31 \\
\hline \multicolumn{3}{|c|}{$\mathrm{KMO}=0.842$} & \multicolumn{4}{|c|}{ Bartlett Test Chi-Square $=801.175$} \\
\hline
\end{tabular}

\subsection{CONFIRMATORY FACTOR ANALYSIS RESULTS (CFA)}

Confirmatory Factor Analysis was conducted to examine the model fit of the scale. The first level factor analysis results are shown in Figure 1. Confirmatory factor analysis model fit index values, X2 / DF $=$ less than 3, NFI $=0.90$ and above, $\mathrm{CFI}=0.95$ and above, GFI $=0.85$ and above, $\mathrm{AGFI}=0.85$ and above, RMSEA if it is $=0.08$ and lower, RMR $=0.08$ and lower, it indicates that the model is congruent (Marcoulides \& Schumacher, 2001). According to the results of the structural equation model created, it was determined that the goodness of fit values were within normal limits (Table 2).

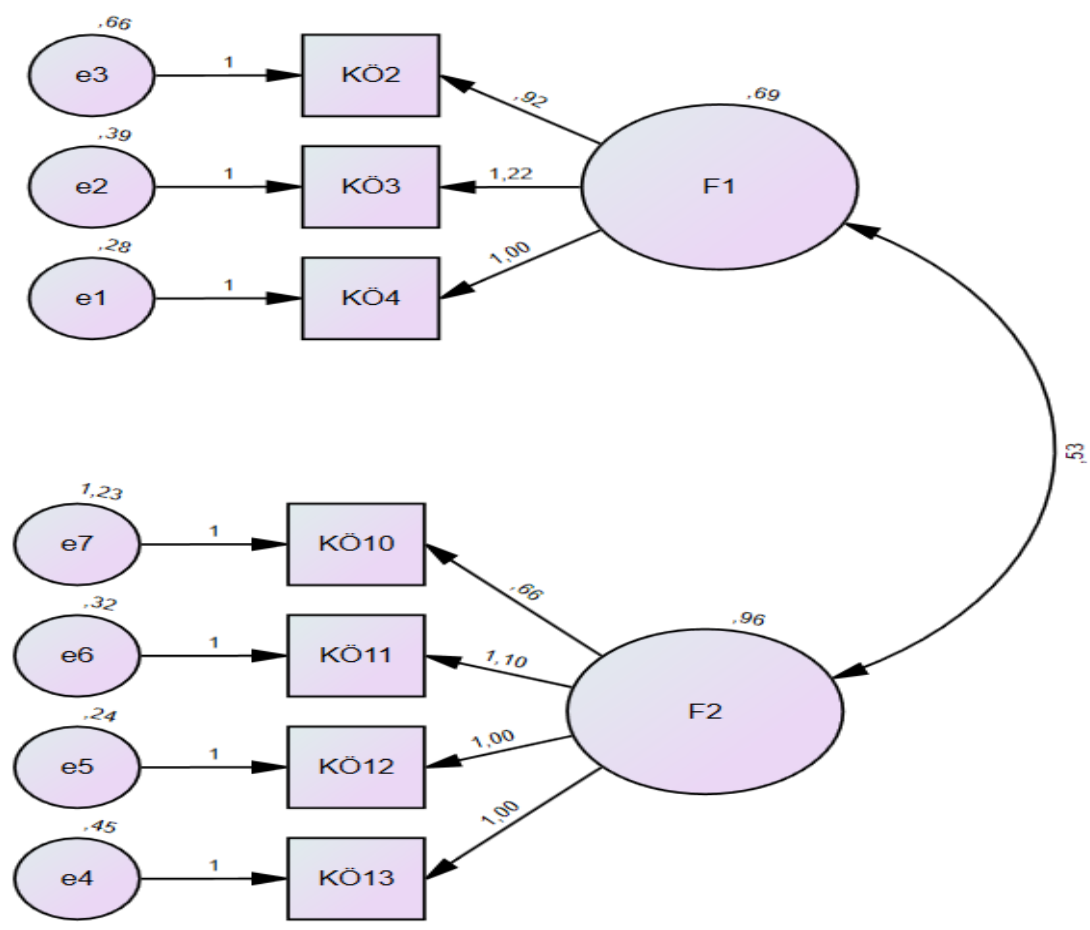

Figure 1: First-level CFA findings

At the end of the analysis, modification indices were examined and a covariance structure between e6 and e7 was proposed. Confirmatory Factor Analysis (CFA) was performed by applying the proposed covariance structure. According to the result of the structural equation model formed, it was determined that the goodness of fit values were within normal limits. 


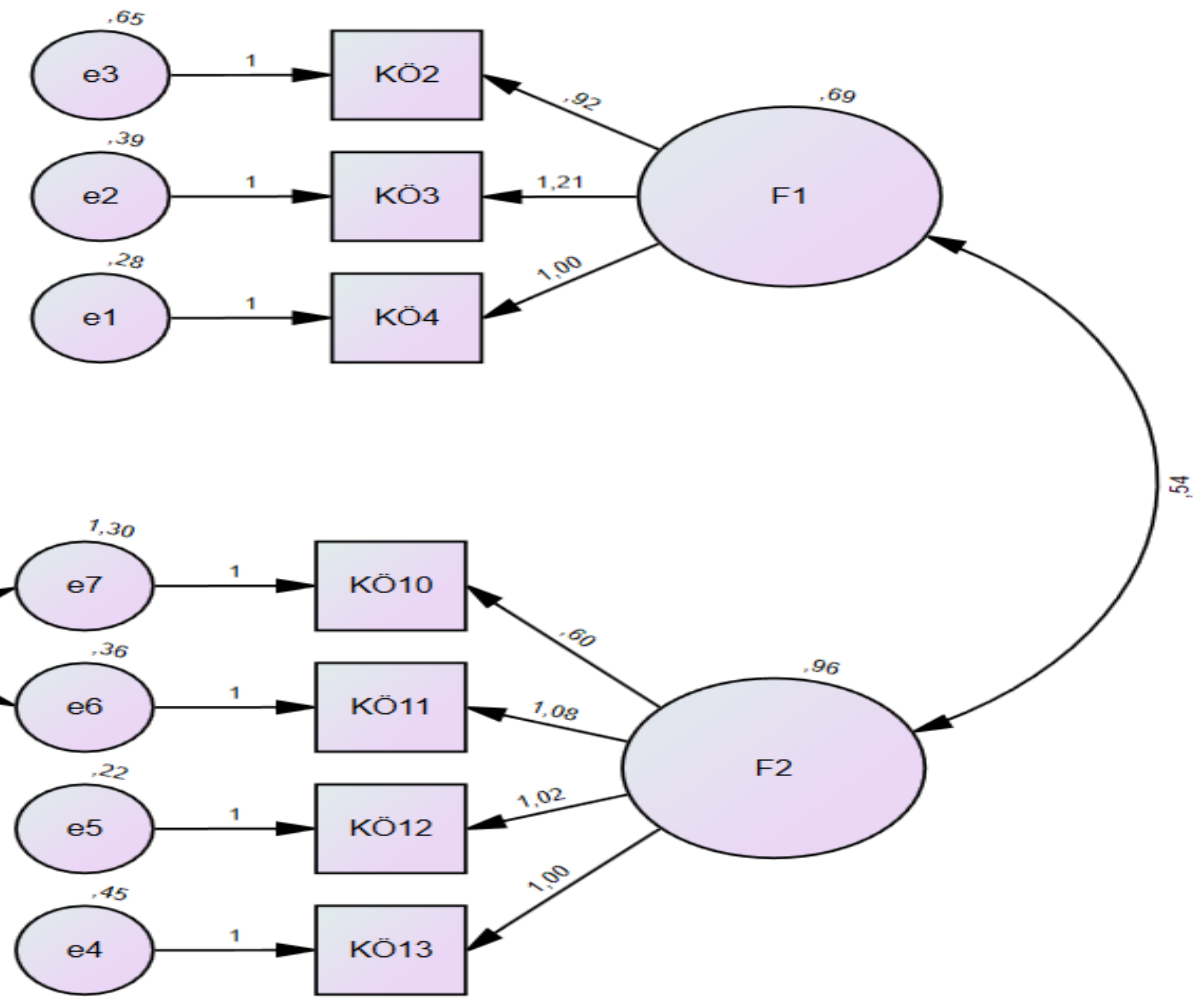

Figure 2: Modified CFA findings

According to the result of the structural equation model formed, it was determined that the goodness of fit values were within normal limits. The model analysis has been completed and the analysis results are shown in Table 2. When the CFA results are examined, it can be said that the goodness of fit values of the modified model are more suitable for this scale.

Table 2: Healthcare Worker Coronavirus Scale CFA findings

\begin{tabular}{|c|c|c|c|c|c|c|c|c|c|c|}
\hline Model & CMIN & DF & $X^{2} /$ DF & $p$ & NFI & CFI & GFI & AGFI & RMSEA & RMR \\
\hline & & & $(\leq 3)^{*}$ & $(>0.05)^{*}$ & $(\geq 0.90)^{*}$ & $(\geq 0.95)^{*}$ & $(\geq 0.85)^{*}$ & $(\geq 0.85)^{*}$ & $(\leq 0.08)^{*}$ & $(\leq 0.08)^{*}$ \\
\hline First level & 26.128 & 13 & 2.010 & 0.016 & 0.968 & 0.983 & 0.964 & 0.923 & 0.070 & 0.054 \\
\hline Modified CFA & 17.519 & 12 & 1.460 & 0.131 & 0.978 & 0.993 & 0.977 & 0.947 & 0.047 & 0.044 \\
\hline
\end{tabular}

* $=$ Reference value.

\subsection{RELIABILITY ANALYSIS FINDINGS OF THE SCALE}

In order to determine the reliability level of the scale, the Cronbach alpha value was calculated by calculating the internal consistency. The findings of the analysis result are shown in Table 3. According to the results, it can be said that both dimensions of the scale are highly reliable $(\mathrm{CA}>0.80)$.

Table 3: Cronbach Alpha reliability test results of the scale

\begin{tabular}{|l|l|}
\hline Scale Dimensions & Cronbach Alfa (CA) \\
\hline Anxiety towards patients (Factor 1) & 0,829 \\
\hline Self anxiety (Factor 2) & 0,851 \\
\hline HECAS & 0,864 \\
\hline
\end{tabular}




\subsection{CORRELATION ANALYSIS RESULTS}

Pearson Correlation Test was conducted to examine the level of correlation between scale factors. As a result of the analysis, a moderate positive relationship was found between both factors $(r=0.536, p<0.01)$.

Table 4: Correlation analysis results

\begin{tabular}{|c|c|c|c|c|}
\hline Dimensions & Mean & SS & 1 & 2 \\
\hline Anxiety towards patients & 2,45 & 0,99 & 1 & \\
\hline Self anxiety & 2,13 & 0,94 & $0,536^{* *}$ & 1 \\
\hline
\end{tabular}

$* *=p<0.01$, SS $=$ Standard deviation

\section{CONCLUSIONS AND RECOMMENDATIONS}

The aim of this study was to develop a scale that includes occupational features to measure the coronavirus anxiety levels of healthcare employees. In the literature, there are scales to measure the anxiety level of individuals, such as the State Anxiety Level Scale and Trait Anxiety Scale by Spielberger et al. (1970), and the Death Anxiety Scale developed by Templer in 1970. Also to measure the Coronavirus Anxiety Scale by Lee (2020) and Silva, Sampaio, Pereire (2020) to measure individuals' coronavirus anxiety levels. However, it has been seen in the literature in a scale that includes the ability to obtain coronavirus anxiety levels of healthcare employees. This study was conducted with the aim of developing a profession-specific scale to measure the coronavirus anxiety levels of healthcare employees. The study I conducted is "Healthcare Employee Coronavirus Anxiety Scale (HECAS)", which consists of two dimensions, "anxiety towards the patient and anxiety towards himself" and 7 items. It was found that the Cronbach Alpha coefficient value was 0.864 and was highly reliable.

It has been found that the alpha coefficient value is 0.864 and is highly reliable.

When the model fit indices of the scale are examined; X2 / DF value $1.460(\leq 3)$ and good level of agreement, GFI value of $0.977(\geq 0.85)$ and good level of agreement, CFI value of $0.993(\geq 0.95)$ and good level of agreement, RMSEA value of $0.047(\leq 0.08)$ and a good level of agreement, with a p value of $0.131(p>0.05)$. As a result, it was determined that the HECAS was compatible with the first level modified CFA result.

It is thought that this scale can be used in studies examining the relationship between coronavirus anxiety levels of healthcare professionals and organizational attitude behaviors.

\section{APPENDICES}

The health worker coronavirus anxiety scale is presented in Appendix A.

Appendix A: Health Employee Coronavirus Anxiety Scale (HECAS)

\begin{tabular}{|c|c|c|c|c|c|c|c|}
\hline & & & $\begin{array}{c}\text { Never } \\
(1)\end{array}$ & $\begin{array}{c}\text { Rarely } \\
(2)\end{array}$ & $\begin{array}{c}\text { Occasionally } \\
(3)\end{array}$ & $\begin{array}{c}\text { Usually } \\
(4)\end{array}$ & $\begin{array}{c}\text { Always } \\
(5)\end{array}$ \\
\hline Self anxiety & $\begin{array}{c}\text { Item } \\
2\end{array}$ & $\begin{array}{c}\text { When caring for my patients or } \\
\text { applying treatment, I am worried about } \\
\text { getting Coronavirus disease. }\end{array}$ & & & & & \\
\cline { 2 - 8 } & $\begin{array}{c}\text { Item } \\
3\end{array}$ & $\begin{array}{c}\text { I feel numbness and tingling in my } \\
\text { hands and feet after caring for the } \\
\text { patient. }\end{array}$ & & & & & \\
\cline { 2 - 9 } & $\begin{array}{c}\text { Item } \\
4\end{array}$ & $\begin{array}{c}\text { I feel palpitations while caring for my } \\
\text { patients. }\end{array}$ & & & & & \\
\hline $\begin{array}{c}\text { Anxiety } \\
\text { towards } \\
\text { patients }\end{array}$ & $\begin{array}{c}\text { Item } \\
10\end{array}$ & $\begin{array}{c}\text { I would be worried about passing the } \\
\text { coronavirus disease to other patients } \\
\text { (cross contamination). }\end{array}$ & & & & & \\
\cline { 2 - 9 } & $\begin{array}{c}\text { Item } \\
11\end{array}$ & $\begin{array}{c}\text { I have difficulty falling asleep due to } \\
\text { the risk of transmitting (cross- }\end{array}$ & & & & & \\
\hline
\end{tabular}




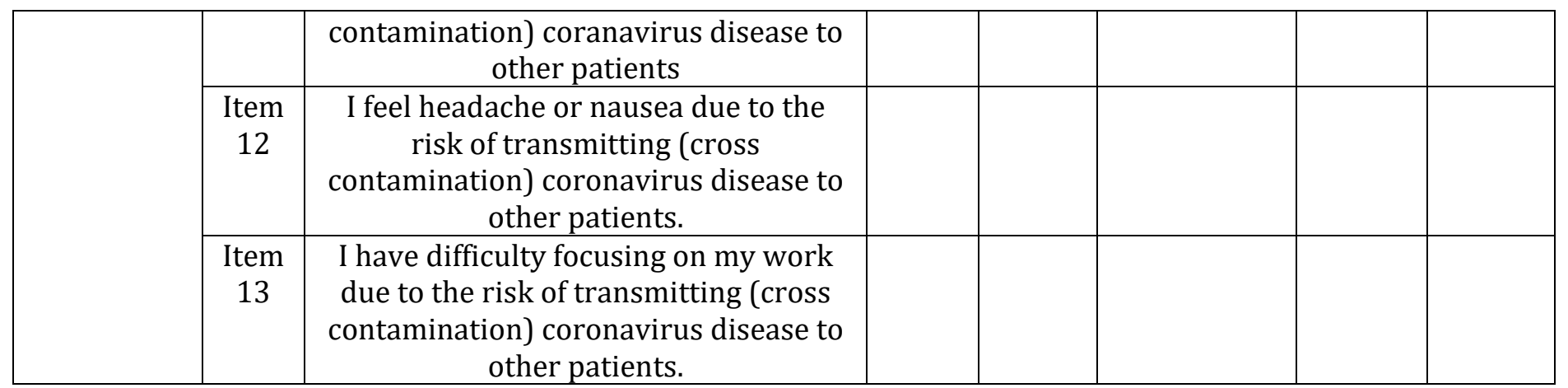

\section{ETHIC}

While conducting this research, the decision of the ethical committee of "Afyon Kocatepe University Social and Human Sciences Scientific Research and Publication Ethics Committee, number 2020/256" was taken that there was no ethical harm.

\section{SOURCES OF FUNDING}

This research received no specific grant from any funding agency in the public, commercial, or not-for-profit sectors.

\section{CONFLICT OF INTEREST}

The author have declared that no competing interests exist.

\section{ACKNOWLEDGMENT}

The author(s) received no financial support for the research, authorship, and/or publication of this article.

\section{REFERENCES}

[1] Aşkın, R., Bozkurt, Y., Zeybek, Z. (2020). Covid-19 Pandemic: Psychological Effects and Therapeutic Interventions. Istanbul Commerce University Journal of Social Sciences, 19 (37), 304-318.

[2] Büyüköztürk, Ş. (2002). Factor Analysis: Basic Concepts and Its Use in Scale Development. Educational Administration: Theory and Practice, 8 (4), 470-483.

[3] Dinesh, S., \& MuniRaju, Y. (2021). Scalability Of E-Commerce in the COVID-19 ERA. International Journal of Research-GRANTHAALAYAH, 9(1), 123-128.

[4] Hutcheson, G. D. \& Sofroniou, N. (1999). The Multivariate Social Scientist: Introductory Statistics Using Generalized Linear Models. London: Sage Publications.

[5] Lee, S. A. (2020). Coronavirus Anxiety Scale: A Brief Mental Health Screener For COVID-19 Related Anxiety. Death studies, 44(7), 393-401.

[6] Marcoulides, G., \& Schumacher, R. (2001). New Developments And Techniques in Structural Equation Modelling. London: Lawrence Erlbaum Associates Publishers.

[7] Nal, M. (2020). Turkey's health policy during COVID-19 pandemic. INSAC Natural and Health Sciences (INHS2020), 286-290.

[8] Seçer, İ. (2015). Psychological Test Development and Adaptation Process; SPSS and Lisrel Applications. Ankara: Anı publishing.

[9] Spielberger, C.D., R.C. Gorsuch, \& R.E. Luschene. (1970). Manual for the State-Trait Anxiety Invenntory. California: Consulting Psychologists Press. 
[10] Tavşancll, E. (2014). Measurement of Attitudes and Data Analysis with SPSS. Ankara: Nobel Academic Publishing.

[11] Templer, D. I. (1970). The Construction and Validation of A Death Anxiety Scale. The Journal of General Psychology, 82(2), 165-177.

[12] Silva, W. A. D., de Sampaio Brito, T. R., \& Pereira, C. R. (2020). COVID-19 anxiety scale (CAS): Development and psychometric properties. Current Psychology, 1-10.

[13] WHO. https://covid19.who.int/. Date of access:07/12/2020. 